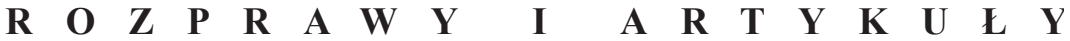

Prawo Kanoniczne 57 (2014) nr 3

\author{
KS. GINTER DZIERŻON
}

Wydział Prawa Kanonicznego

Uniwersytetu Kardynała Stefana Wyszyńskiego w Warszawie

\section{PROCES UZNANIA AUTONOMII PRAWA WŁASNEGO WSPÓLNOT KOŚCIELNYCH W KANONICZNYM PORZĄDKU PRAWNYM}

Treść: Wstęp. - 1. Wspólnoty kościelne. - 2. Problem autonomii systemów prawnych Wspólnot kościelnych w kanonistyce posoborowej. - 3. Wkład Sygnatury Apostolskiej w uznanie autonomii innych systemów prawnych. - 4. Problem autonomii systemów prawnych Wspólnot kościelnych w pracach nad kodyfikacją wschodnią. 5. Uznanie autonomii prawa własnego Wspólnot eklezjalnych w Kodeksie Kanonów Kościołów Wschodnich (kan. $780 \S 2$, n. 1). - 6. Uznanie autonomii prawa własnego Wspólnot kościelnych w łacińskim porządku prawnym (art. 2 §, n. 1 DC). Zakończenie.

\section{Wstęp}

W kanonicznym porządku prawnym podejmują akty i działania prawne nie tylko katolicy, ale także akatolicy niepodlegający jurysdykcji prawodawcy kościelnego. Niejednokrotnie bywa tak, że wierni innych wyznań uprzednio dokonują czynności według zasad własnego sytemu prawnego. W tym kontekście z aspektu kanonistycznego powstaje pytanie o walor rozwiązań porządków prawnych innych Kościołów i Wspólnot kościelnych? Dzisiaj nie ma wątpliwości co do tego, że ustawodawca katolicki w kan. 780 § 2, n. 1 KKKW oraz w art. $2 \S 2$, n. $1 \mathrm{DC}^{1}$ zaakceptował autonomię prawa własnego akatolickich Kościołów i Wspólnot kościelnych. Obecny stan prawny jest rezultatem ogromnego wysiłku doktryny i judykatury zmierzającego

1 Por. Pontificium Consilium de Legum Textibus, Instructio Dignitas connubii 25. 01. 2005, Città del Vaticano 2005, s. 3, (dalej: DC). 
do przyznania statusu autonomicznego w systemie kanonicznym ustaleń funkcjonujących w innych porządkach prawnych. Przez długi okres czasu w ustawodawstwie katolickim, jak i doktrynie wykluczano kategorycznie taką ewentualność. Ewolucja podejścia Kościoła do tego problemu nastąpiła pod wpływem doktryny Soboru Watykańskiego II.

W niniejszym opracowaniu zostanie ukazany proces uznania autonomii prawa własnego Wspólnot kościelnych w kanonicznym porządku prawnym.

\section{Wspólnoty kościelne}

Ze względu na podjętą problematykę w pierwszym rzędzie trzeba zapytać: jakie treści kryją się pod pojęciem „Wspólnoty kościelne”? Zajmując się tym problemem K. Lüdicke stwierdził, iż w tym przypadku idzie o wspólnoty Kościoła Jezusa Chrystusa, w których nie zachowano sakramentu święceń ${ }^{2}$. Twierdzenie tego niemieckiego kanonisty nie do końca jest precyzyjne. Do tej kwestii odniesiono się bowiem w doktrynie Soboru Watykańskiego, wyrażonej w sposób szczególny w „Dekrecie o ekumenizmie”. W dokumencie tym skonstatowano, że wspólnoty te nie zachowały istoty eucharystycznego misterium ze względu na brak sakramentu kapłaństwa (DE 22).

Prawdę tę potwierdzono w opublikowanej w dniu 6 sierpnia 2000 r. Deklaracji Kongregacji Nauki Wiary „,Dominus Jesus”. Nawiązując do n. 22 soborowego DE podkreślono, że idzie o społeczności, które nie zachowały ,prawomocnego Episkopatu oraz całkowitej rzeczywistości eucharystycznego misterium" ". Ta Dykasteria wyjaśniła również tę kwestię w kolejnym dokumencie „Odpowiedzi na pytania dotyczące niektórych aspektów nauki o Kościele". Odpowiadając na pytanie: dlaczego wspólnotom chrześcijańskim powstałym w następstwie Reformy XVI w. nie przypisuje się tytułu Kościoła podkreślono, że takie rozumienie wynika $\mathrm{z}$ faktu, że we wspólnotach tych nie istnieje

2 Por. K. LüDICKE, „Dignitas connubi”. Die Eheprozeßordnung der katholische Kirche, Essen 2005, s. 11: „Unter kirchlichen Gemeinschaften versteht die Instruktion solche Teilgemeinschaften der Kirche Jesu Christi, die das Weihesakrament nicht bewahrt haben".

3 Zob. Kongregacja Nauki Wiary, Deklaracja „,Dominus Jesus”, Warszawa 2000, s. 37. 
kapłaństwo sakramentalne oraz „właściwa i integralna rzeczywistość Misterium Eucharystycznego"4.

\section{Problem autonomii systemów prawnych Wspólnot kościelnych w kanonistyce posoborowej}

W doktrynie wskazuje się, iż pomimo tego, że Sobór Watykański II uznał Wspólnoty kościelne Zachodu za Wspólnoty eklezjalne (DE 3) to jednak nie odniósł się on wyraźnie do problemu ich zdolności do stworzenia własnego systemu prawa ${ }^{6}$. Z perspektywy czasu bardzo trudno jest odpowiedzieć na pytanie jakie były przyczyny takiego stanu rzeczy; czy było to tylko zwykłe niedopatrzenie, czy też należałoby raczej mówić o celowym pominięciu tej kwestii?

Wobec tego, wielu autorów w okresie posoborowym pytało: czy może istnieć wspólnota kościelna bez władzy stanowienia własnego prawa?7. Wątpliwości te były tym bardziej zasadne ze względu na fakt, iż Sobór w sposób wyraźny w „Deklaracji o wolności religijnej” (DWR) opowiedział się zdolnością religii niechrześcijańskich do stanowienia własnego prawa ${ }^{8}$. W n. 4 tego dokumentu czytamy: „Tym więc wspólnotom, jeżeli tylko nie naruszają one słusznych wymagań porządku publicznego prawnie należy się nietykalność, by rządziły się własnym prawem".

Komentując naukę Vaticanum II kanoniści zwracali uwagę, że doktrynalnie nie dało się wywieść zdatności Wspólnot kościelnych do sta-

${ }^{4}$ Por. Kongregacja Nauki Wiary, Odpowiedzi na pytania dotyczace niektórych aspektów nauki o Kościele - 29. 06. 2007, http://www.vatican.va/roman_curia/congregations/cfaith/documents/rc_cfaith_doc_20070629_responsa-quaestiones_pl.htlm (dostęp 1. 12. 2013).

5 Szerzej na temat posoborowej dyskusji nad tym problemem zob. A. SKowroneK, Światła ekumenii, Warszawa 1984, s. 44-48.

6 Por. U. Breitbach, Die Vollmacht der Kirche Jesu Christi über die Ehen der Getauften, Roma 1998, s. 108.

7 Tamże.

${ }^{8}$ Por. B. Berkmann, Die Ehe von/mit nichtkatholiken vor der Lateinischen Kirche, Frankfurt am Mein 2008, s. 71.

9 Por. G. DzIERżon, Walor systemów prawnych religii niechrześcijańskich w prawie matżeńskim Kościoła katolickiego, Przegląd Prawa Wyznaniowego 5(2013), s. 43-44. 
nowienia własnego prawa z tak istotnej przesłanki jaką jest władza rządzenia ${ }^{10}$. Autorytety bowiem tych społeczności nie są wyposażone w nią, ponieważ we wspólnotach tych nie zachowano sukcesji apostolskiej ${ }^{11}$. Taki pogląd wyraził U. Navarrete twierdząc, że wspólnoty eklezjalne nie dysponują tego typu władzą, gdyż nie mają sukcesji apostolskiej $^{12}$. Popierając to twierdzenie odwołał się on do noty eksplikatywnej zawartej w soborowej „Konstytucji Dogmatycznej o Kościele” o następującej treści: „Święcenia biskupie, wraz z płynącą z nich misją uświęcania, przynoszą również funkcje nauczania i kierowania, które jednak ze swej natury mogą być wykonywane tylko w hierarchicznej komunii z głową kolegium i jego członkami” (KK 21) ${ }^{13}$.

Inni kanoniści okresu posoborowego niepodzielając tego poglądu obrali nieco inny kierunek interpretacyjny. Utrzymywali oni, że w dokumentach soborowych nie występuje wprawdzie wyraźne odniesienie do problemu autonomii porządków prawnych Wspólnot kościelnych; w ich przekonaniu jednak, w doktrynie soborowej nawiązano do tej kwestii w sposób „implicite"14. W swych argumentacjach posiłkowali się oni różnymi tekstami soborowymi. J. Prader odwołując się do przytaczanego już tekstu DWR 4 podkreślił, iż z faktu, że na Soborze uznano status Wspólnot eklezjalnych dedukcyjnie można przyjąć, iż ze swej natury posiadają one zdolność do stanowienia prawa ${ }^{15}$.

Na DWR 4, a szczególnie na DE 23 powołał się R. Sobański w swym artykule „Ökumenismus und Verwirklichung der Grundrech-

${ }^{10}$ Szerzej na temat pojmowania władzy rządzenia zob. K. Mörsdorf, Fondamenti del diritto canonico, tłum. S. Testa Bappenheim, Venezia 2008, s. 220-221.

${ }^{11}$ U. Breitbach, Die Vollmacht der Kirche..., s. 108.

${ }^{12}$ Por. U. Navarrete, Competentia Ecclesiae in matrimonium baptizatorum eiusque limites, Periodica 67(1978), s. 104-105: „Hoc posito patet communitates ecclesiales in quibus non habetur succesio apostolica non posse sibi dare leges quae vim habeant ex propriis rectoribus immediate promanentem".

${ }^{13}$ Por. U. Navarrete, La giurisdizione delle Chiese orientali non cattoliche sul matrimonio (can. 780 C.C.E.O.), w: Il matrimonio nel Codice dei canoni delle Chiese Orientali, Città del Vaticano 1994, s. 109.

${ }^{14}$ Por. M. Zaborowski, Nabycie przynależności do Kościoła katolickiego, Lublin 2013, s. 167.

${ }^{15}$ Por. J. Prader, Il matrimonio in Oriente e in Occidente, Rome 2003, s. 57. 
te der Getauften". Twierdził on, iż w treści tego ostatniego dokumentu wyróżniono elementy charakterystyczne dla funkcjonowania tych wspólnot w wymiarze prawnym. W jego przekonaniu, aprobata pewnego stylu życia świadczy, ,implicite” o zdatności społeczności do tworzenia prawnie wiążących struktur ${ }^{16}$.

Wreszcie jeszcze inni uczeni wywodzili autonomię systemów prawnych ze znanej zasady prawa rzymskiego ,ubi societas ibi ius"17.

\section{Wkład Sygnatury Apostolskiej w uznanie autonomii innych systemów prawnych}

Ewolucja myśli Kościoła w przedmiocie ujętym w tytule opracowania rozpoczęła się od akceptacji autonomii dyscypliny akatolickich Kościołów Wschodnich. Wydaje się, iż przyjęcie takiego rozwiązania tej kwestii było łatwiejsze, ponieważ na Soborze akatolickie Kościoły Wschodnie uznano za Kościoły.

W pierwszym rzędzie zapoczątkowany proces znalazł swój wyraz w nowatorskich jak na owe czasy rozstrzygnięciach Sygnatury Apostolskiej w sprawach o nieważność małżeństwa z powodu braku udziału świętego szafarza.

W dniu 28 listopada 1970 r. Trybunał ten orzekł nieważność małżeństwa wiernych rytu bizantyjsko - rumuńskiego, zawartego z pomi-

${ }^{16}$ Por. R. SoBAŃSKI, Ökumenismus und Verwirklichung der Grundrechte der Getauften, w: Die Grundrechte des Christen in Kirche und Gesellschaft, red. E. Corecco, N. Herzog, A. Scola, Freiburg - Mailand 1981, s. 719-720: „Obwohl das Dekret über Ökumenismus ihre Disziplin expressis verbis nicht erwähnt, so weist es doch auf den christlicher Lebenswandel dieser Gemeinschaften hin, der sich im Alltag und in religiösen Versammlungen ausdrückt und seine Früchte zetigt, $\mathrm{u}$ a. im lebendigen Gerechtigkeitsgefühl und in tätiger Nächstenliebe (UR 23). Es werden also Elemente anerkannt, die den Inhalt des Rechtslebens bilden, unabhängig davon, ob sie in den betreffenden Lebensstils und seine Beurteilung enhält implicite eine Feststellung der Fähigkeit, verbindliche Rechtsstrukturen auszubilden, die ja untrennbar mit dem Stil des sozialen Lebens verbunden sind".

${ }^{17}$ B. Berkmann, Die Ehe..., s. 71-72. Szerzej na temat tej zasady zob. T. GaŁKowSKI, Ubi societas ibi ius w czasach globalizacji, w: Ars boni et aequi. Księga pamiątkowa dedykowana Księdzu Profesorowi Remigiuszowi Sobańskiemu z okazji osiemdziesiątej rocznicy urodzin, red. J. Wroceński, H. Pietrzak, Warszawa 2010, s. 617. 
nięciem rytu świętego ${ }^{18}$. Z kolei w dniu 7 lipca 1971 r. za nieważny uznano związek zawarty między wiernymi rytu bizantyjsko - rumuńskiego, ze względu na brak udziału świętego szafarza ${ }^{19}$. Z podobnego powodu w dniu 18 kwietnia 1972 r. stwierdzono nieważność małżeństwa zawartego między wiernym Kościoła greko - ortodoksyjnego i anglikaninem ${ }^{20}$. Wreszcie w dniu 23 listopada 1974 r. podjęto decyzję „pro nullitatae” w odniesieniu do związku schizmatyckich Ormian, $\mathrm{z}$ racji braku formy, czyli braku rytu świętego ${ }^{21}$.

P. V. Pinto oceniając wkład jurysprudencji Sygnatury Apostolskiej $\mathrm{w}$ akceptację autonomii innych systemów prawnych w systemie kanonicznym podkreślił, iż jest on porównywalny do wkładu judykatury Roty Rzymskiej w kodyfikację kan. $1095 \mathrm{KPK}^{22}$.

\section{Problem autonomii systemów prawnych Wspólnot kościelnych w pracach nad kodyfikacją wschodnią}

Problem akceptacji prawa własnego Wspólnot kościelnych został podjęty podczas prac nad pierwszą kodyfikacją katolickich Kościołów Wschodnich. W 1977 r. w trakcie obrad Zespołu konsultorów zajmujących się prawem małżeńskim zaproponowano wprowadzenie regulacji w której znalazłoby się wyraźne odniesienie do kwestii specyficznych

${ }^{18}$ Por. Signatura Apostolica, Nullitas matrimonii inter Orthodoxos absque ritu sacro initi declaretur, et modus procedendi in iisdem similibusque causis statuitur, w: Leges Ecclesiae, red. F. Ochoa, t. 4, Roma 1974, kol. 5927-5928.

${ }^{19}$ Por. Signatura Apostolica, De nullitate matrimonii inter duos orthodoxos ritus byzantini-romeni initi absque ritu sacro, w: Leges Ecclesiae, red. F. Ochoa, t. 4, Roma 1974, t. 4, kol. 6135-6136.

${ }^{20}$ Por. Signatura Apostolica, Matrimonium inter partes graeco - orthodoxam et anglicanam coram ministro anglicano initum declarai potest nullum ob defectum ritus sacri si partes ministrum orthodoxum in loco commode adire poterant, w: Leges Ecclesiae, red. F. Ochoa, t. 4, Roma 1974, kol. 6257-6258.

${ }^{21}$ Por. Signatura Apostolica, Nullitas matrimonii inter schismaticos armenos contracti declaratur ob defectum formae seu ritus sacri, w: Leges Ecclesiae, red. F. Ochoa, t. 4, Roma 1980, Leges Ecclesiae, red. F. Ochoa, t. 5, kol. 6891-6895.

${ }^{22}$ Por. P. PInTo, Gli articoli preliminari (artt. 1- 7) della Dignitas Connubii, w: Il giudizio della nullità dopo l'istruzione „Dignitas Connubii”, red. P. Bonnet, C. Gullo, t. 2, Città del Vaticano 2007, s. 21. 
rozwiązań prawnych Wspólnot eklezjalnych. Postulowana norma miała następujące brzmienie: w rozstrzyganiu spraw o ważność małżeństwa osób niepodlegających prawu kościelnemu należy wziąć pod uwagę ich prawo własne, z zachowaniem prawa Bożego naturalnego i pozytywnego $0^{23}$.

W czasie dyskusji niektórzy uczestnicy byli przeciwni tej propozycji. Jeden z nich przekonywał, że konceptu małżeństwa funkcjonującego w akatolickich Kościołach Wschodnich nie można traktować na równi z konceptem małżeństwa występującym u protestantów; w tych pierwszych bowiem związek małżeński jest sakramentem; nie ma on natomiast takiego charakteru u protestantów ${ }^{24}$.

Do interesującego nas zagadnienia powrócono jeszcze na początku 1978 r. W trakcie obrad dyskutowano bowiem nad wątpliwością: jakie prawo należy aplikować w sytuacji, gdy akatolicy nie podlegają katolickim regulacjom dotyczącym przeszkód zrywających i formy kanonicznej? Odpowiadając na tę trudność Relator J. Prader opowiedział się za rzeczywistym przejęciem akatolickich przepisów w systemie kanonicznym. Przekonywał on, iż mechanizm recepcji polegałby na tym, że w tym wypadku nie należałoby mówić o ich kanonizacji, ale o formalnej akceptacji ${ }^{25}$.

${ }^{23}$ Por. Disputationes Coetus Consultorum «De lege matrimoniali applicanda», Nuntia 5(1977), s. 53; Propozycja regulacji brzmiała następująco: „In diiudicanda validitate matrimonii inter personas quae legibus ecclesiaticis non sunt subiecta, leges propriae, quibus ipsae tenetur, attendae sint, salvo iure divino positivo aut naturali"; U. Breitbach, Die Vollmacht der Kirche..., s. 198.

${ }^{24}$ Disputationes Coetus Consultorum «De lege matrimoniali..., s. 54: „Non eadem criteria applicari possunt in iudicanda validitate matrimonii initi inter Protestantes. Dum in Ecclesiis Orthodoxis matrimonium est verum sacramentum et disciplina ecclesiastica regitur. Protestantes generatim negant matrimonium esse sacramentum idque uti contractum civilem auctoritati saeculari subiectum declarunt praesertim quod attinet ad impedimenta iuris humani et effectus iuridicos. Tamen matrimonium christianum - secundum eorum doctrinam - non est conctractus tantummodo civilis, sed negotium cui per institutionem divinam charakter spiritualis est impressus. Ideo etiam inter Protestantes matrimonium numquam ex toto saeculari potestati relinquebatur, saltem relate ad admissione ad celebrationem religiosam matrimonii".

${ }^{25}$ Por. Labor Consultorum Commisionis circa canones de Matrimonio (Mons. Joseph Prader, Relator), Nuntia 8(1979), s. 6: „Non agitur de «canonizatione» legum 
Podczas polemiki powstała też wątpliwość: jakie prawo przeważyłoby, jeśli uznano by prawo własne innych wspólnot w przypadku podejmowania aktów mieszanych? Problem ten rozważano w kontekście pytania o walor przeszkód małżeńskich; pytano czy nieochrzczeni akatolicy zawierający związek małżeński w Kościele podlegaliby przeszkodom kościelnym Kościoła katolickiego, czy też przeszkodom własnego Kościoła? J. Prader opowiadając się za przyznaniem autonomii rozwiązaniom innych Wspólnot, wyjaśniając złożony problem posłużył się następującym przykładem pytając: czy katolik zawierający małżeństwo z kobietą prawosławną mającą 16 lat, której prawo własne do zawarcia małżeństwa wymagało 18 lat może zawrzeć ważne małżeństwo tylko ze swojej strony, a nieważne ze strony ze strony prawosławnej. Uważał on, iż takie rozumienie jest niewłaściwe, gdyż zgodnie z założeniami systemowymi małżeństwo jest ważne lub nieważne dla obu stron ${ }^{26}$. W tym wypadku o nieważności związku decydowałoby prawo akatolickie.

Zaprezentowane przed chwilą wysiłki zaowocowały akceptacją autonomii systemów prawnych Wspólnot eklezjalnych w Kodeksie Kanonów Kościołów Wschodnich.

\section{Uznanie autonomii prawa własnego Wspólnot eklezjalnych} w Kodeksie Kanonów Kościołów Wschodnich (kan. 780 § 2, n. 1)

Prace Komisji Kodyfikacyjnej doprowadziły do skodyfikowania kan. $780 \S 2$, n. 1 KKKW. W regulacji tej uznano w sposób wyraźny autonomię systemów prawnych Wspólnot eklezjalnych. Treść tej normy jest następująca: „Małżeństwo między stroną katolicką i stroną ochrzczoną akatolicką, z zachowaniem Prawa Bożego, jest regulowane także: prawem własnym Kościoła lub Wspólnoty kościelnej, do której należy strona akatolicka, jeśli ta Wspólnota posiada własne prawo małżeńskie”.

W kontekście prowadzonych dociekań należy zauważyć, że w wydaniu źródłowym Kodeksu Kanonów Kościołów Wschodnich do

non catholicorum, sed de mera acceptazione formali discplinae qua non catholici de facto tenentur".

${ }^{26}$ Tamże, s. 7-8. 
przytoczonego kanonu podano tylko dwa źródła, jakimi są DE 16 oraz DWR $4^{27}$. Oznacza to zatem, iż wysiłki doktryny zmierzające do wykazania, że Wspólnoty kościelne z natury rzeczy są zdatne do stworzenia własnych porządków prawnych znalazły zwieńczenie w zapisie kan. $780 \S 2$, n. 1 KKKW.

W swej wykładni tego kanonu D. Salachas powołując się na DWR 4 stwierdził, że Sobór w sposób „explicite” opowiedział się za autonomią porządków prawnych wspólnot eklezjalnych ${ }^{28}$. Nie do końca przekonuje ten pogląd. Wydaje się bowiem, iż ten komentator wywiódł to twierdzenie $\mathrm{z}$ treści skodyfikowanego przepisu; nie wziął on natomiast pod uwagę posoborowych opinii kanonistów, którzy skłaniali się ku tezie, że zdolność o której mowa wynika jedynie w sposób pośredni $\mathrm{z}$ tekstów soborowych.

Rozwiązanie zawarte w kan. $780 \S 2$, n. 1 KKKW stało się faktem. Komentatorzy zwracali jednak uwagę, że podobne ujęcie nie występowało w kodyfikacji łacińskiej. W tej materii więc wystąpiła typowa luka prawna ${ }^{29}$. Ich uwagi zaowocowały tym, że po ponad 20. latach ujęcie występujące w legislacji wschodniej znalazło się również w art. $2 \S 2$, n. 1 DC.

\section{Uznanie autonomii prawa własnego Wspólnot kościelnych w lacińskim porządku prawnym (art. 2 2, n. 1 DC)}

W art. $2 \S 2$, n. 1 DC postanowiono. „Małżeństwo między stroną katolicką i stroną ochrzczoną niekatolicką, jest regulowane także: prawem

${ }^{27}$ Por. Kodeks Kanonów Kościołów Wschodnich promulgowany przez papieża Jana Pawła II, Lublin 2002, s. 514; B. Berkmann, Die Ehe..., s. 72.

${ }^{28}$ Por. D. SAlachas, Il sacramento del matrimonio nel Nuovo Diritto Canonico delle Chiese orientali, Bologna 1994, s. 60.

${ }^{29}$ U. NAVArRete, La giurisdizione..., s. 118-119; Tenże, Ius matrimoniale latino e orientale, Periodica 80(1991), s. 636-639; L. Lonusso, Gli orientali cattolici e/i pastori latini, Roma 2003, s. 222-223; U. NowICKA, Apilikacja prawa przy zawieraniu małżeństw z akatolikami wedtug legislacji łacińskiej $i$ wschodniej, w: Finis legis Chiristus. Księga pamiątkowa dedykowana Księdzu Profesorowi Wojciechowi Góralskiemu z siedemdziesiątej rocznicy urodzin, red. J. Wroceński i J. Krajczyński, t.1, Warszawa 2009, s. 641-657; U. NowICKA, Stwierdzenie stanu wolnego wiernych prawosławnych na forum Kościoła katolickiego, Warszawa 2012, s. 185-190. 
własnym Kościoła lub Wspólnoty kościelnej, do której należy strona akatolicka, jeśli ta Wspólnota posiada własne prawo małżeńskie". Według kanonistów, rozwiązanie to jest wyrazem wrażliwości ekumenicznej ${ }^{30}$.

W literaturze przedmiotu podkreśla się, że na przytoczony zapis wywarła poważny wpływ eklezjologia soborowa. Należy przypomnieć, że w czasach przedsoborowych nieco inaczej postrzegano problem podlegania osób prawu kościelnemu. Pod rządami Kodeksu pio - benedyktyńskiego bowiem do zachowania ustaw czysto kościelnych nie byli zobligowani jedynie ci, którzy nie przyjęli chrztu; wszyscy inni ochrzczeni, w tym również akatolicy byli zobowiązani do zachowania ustawodawstwa kościelnego (kan. $12 \mathrm{KPK}$ ). Tego typu podejście wynikało z eklezjologicznej doktryny identyfikującej całkowicie Kościół katolicki z Kościołem Jezusa Chrystusa, co znajdowało wyraz w tezie „Ecclesia Christi est Ecclesia catholica" ${ }^{1}$. Z takim rozumieniem spotykamy się jeszcze w opublikowanej w dniu 29 czerwca 1943 r. przez papieża Piusa XII encyklice „Mistici Corporis Christi”. W dokumencie tym ojciec św. powołując się na Konstytucję Soboru Watykańskiego I „Dei Filius” podkreślił, iż prawdziwym Kościołem Chrystusowym jest święty, katolicki, apostolski Kościół Rzymski². Rozważając zaś problem przynależności prawnej wiernych do Kościoła nawiązał on do doktryny R. Belarmina wskazując na więzy wiary, sakramentów i zwierzchnictwa kościelnego ${ }^{33}$.

Jak już zasygnalizowano, do zmiany wizji w interesującej nas kwestii przyczyniła się w głównej mierze eklezjologia Soboru Watykańskiego $\mathrm{II}^{34}$. Zdaniem P. Gherriego, Sobór dogłębnie odnowił strukturę widzialną Kościoła poprzez odniesienie do źródeł biblijnych i teologicznych $^{35}$. Fundamentem zrewidowanego spojrzenia na Kościół sta-

\footnotetext{
${ }^{30}$ Por. J. Llobell, Commento al art. 2 DC, w: Norme procedurali canoniche commentate, red. M. del Pozzo, J. Llobell, J. Miñambres, Roma 2013, s. 269.

${ }^{31}$ M. ZABorowski, Nabycie przynależności..., s. 158-162.

${ }^{32}$ Por. PIus XII, Encyclica Mistici Corporis Christi - 29. 06. 1943, w: Enchiridion delle Encicliche, t. 6, Bologna 1995, s. 144.

${ }^{33}$ Tamże, s. 194 i 196.

${ }^{34}$ P. PINTO, Gli articoli preliminari..., s. 21.

${ }^{35}$ Por. P. Gherri, Lezioni di Teologia del Diritto Canonico, Roma 2004, s. 236.
} 
nowiło jego ujęcie w kategoriach „,communio"36. W następstwie czego, zmianie uległ pryncypialny paradygmat eklezjologiczny. Obecnie wyraża się on w stwierdzeniu „Haec Ecclesia subsitit in Ecclesia catholica" (KK 8, DE 4; DWR 1) ${ }^{37}$. Trzeba dodać, iż pryncypium to zostało również wpisane w brzmienie kan. 204 § 2 i kan. 7 § 2 KKKW. Zasadnicze racje przemawiające za zmianą opcji wynikały z treści zawartych w KK 15 oraz DE 3 i 19 w których uznano, że we Wspólnotach kościelnych istnieją także elementy eklezjalne ${ }^{38}$. Do tej kwestii nawiązano we wspomnianym już dokumencie Kongregacji Nauki Wiary „Odpowiedzi na pytania dotyczące niektórych aspektów nauki o Kościele”. Na trzecie pytanie: dlaczego w dokumentach nie posłużono się słowem ,jest", lecz użyto zwrotu ,trwa w" (subsistit in) odwołując się do KK 8, 2 i DE 3, 4 udzielono następującej odpowiedzi „Użycie tego wyrażenia, które oznacza pełną identyczność Kościoła Chrystusowego z Kościołem katolickim, nie zmienia doktryny o Kościele, a swoją prawdziwą motywację znajduje w tym, że jaśniej wyraża fakt, iż poza jego organizmem znajdują się «liczne pierwiastki uświęcenia i prawdy» [...] «Dlatego Kościoły i Wspólnoty odłączone, choć w naszym przekonaniu podlegają brakom, wcale nie są pozbawione znaczenia i wagi w tajemnicy zbawienia» $[\ldots]^{\prime \prime 39}$.

Z komponentów eklezjalności współczesna doktryna wywodzi zdolność wspólnot eklezjalnych do tworzenia własnych, autonomicznych porządków prawnych ${ }^{40}$.

${ }^{36}$ Szerzej na temat koncepcji Kościoła jako „communio” zob. M. Żurowski, ,, Communio ecclesiarum '. L'uomo nella communità ecclesiale delle communità, Ius Canonicum 17(1977), s. 209-221; M. ŻUROWSKI, Wspólnota kościelna „,communio” podstawa prawa kościelnego, Prawo Kanoniczne 20(1977) nr 1-2, s. 67-85; M. ŻURowski, „Communio” a jedność partykularnej wspólnoty wspólnot, Analecta Cracoviensia 10(1978), s. 359-368.

${ }^{37}$ Por. B. Zотz, Katholisch getauft - katholisch geworden, Essen 2002, s. 135; M. Zaborowski, Nabycie przynależności..., s. 164-165.

${ }^{38}$ B. Berkmann, Die Ehe..., s. 73.

${ }^{39}$ KongregacJa NaUKI Wiary, Odpowiedzi..., http://www.vatican.va/roman_curia/ congregations/cfaith/documents/rc_cfaith_doc_20070629_responsa-quaestiones pl.htlm (dostęp 1 grudnia 2013 r.), s. 2.

${ }^{40}$ B. Berkmann, Die Ehe..., s. 73. 
Odnosząc się do tego wątku A. Abate podkreślił, iż na Soborze Watykańskim II w sposób ,implicite” uznano ich zdolność do tworzenia prawa. Każda wspólnota religijna bowiem nie na mocy decyzji ludzkiej, ale ze swej natury ma prawo do rządzenia się własnym prawem $^{41}$. Na opinię wyrażoną przez tego włoskiego kanonistę powołał się A. Stankiewicz w wyroku Roty Rzymskiej, opublikowanym w dniu 27 marca 1998 r. Konstruując argumentację ,,in iure” ponens stwierdził, iż chociaż brak jest wyraźnego odniesienia do tej kwestii w dokumentach soborowych, to jednak w sposób pośredni (implicite) z takim odniesieniem spotykamy się w DWR 4, gdyż każda wspólnota religijna nie przez decyzję ludzką, ale ze swej natury ma prawo do rządzenia się własnym prawem ${ }^{42}$. Do jeszcze szerszego spektrum źródeł odwołał się A. Stankiewicz w swym komentarzu do art. $2 \S 2$, n. 1 DC. W tym wypadku przywołał on kan. 780 § 2 KKKW i źródła soborowe, które w głównej mierze wpłynęły na jego kodyfikację (DWR 4 i DE 16) ${ }^{43}$.

P. V. Pinto komentując art. $2 \S 2, n .1$ DC nawiązał do przytaczanej już opinii wyrażonej przez J. Pradera podczas prac kodyfikacyjnych. Stwierdził on, iż w tym wypadku nie idzie o kanonizację, ale o prawdziwą recepcję rozwiązań innego systemu prawnego ${ }^{44}$.

\section{Zakończenie}

Z przeprowadzonych analiz wynika, że akceptacja w dyscyplinie i doktrynie katolickiej zdolności Wspólnot kościelnych do tworzenia własnego systemu prawnego była długim procesem. Zasadniczy

${ }^{41}$ Por. A. Abate, Il matrimonio nella nuova legislazione canonica, Roma 1985 , s. 26: „Invece, per quanto concerne le chiese o communità separate in occidente non esiste un uguale esplicito enunciato conciliare, anche perché, in genere, presso di esse, non è in grande stima l'elemento visibile e giuridico. Tuttavia è riconosciuta loro la stessa facoltà, almeno implicitamente, in forza della dichiarazione conciliare sulla libertà religiosa. È qui afermato, come principio generale, che ogni communità religiosa, non per concessione dell'autorità umana, ma per la sua stessa natura, ha il diritto di reggersi con leggi proprie [...]"'.

${ }^{42}$ Por. Dec. c. Stankiewicz - 27. 03. 1998, RRD 90(1998), s. 337.

${ }^{43}$ Por. A. Stankiewicz, Komentarz do art. 2 DC, w: Komentarz do Instrukcji procesowej ,,Dignitas connubii”, red. T. Rozkrut, Sandomierz 2007, s. 25.

${ }^{44}$ P. PINTO, Gli articoli preliminari..., s. 21. 
wpływ na obecny stan prawny wywarła nauka Soboru Watykańskiego II, a w sposób szczególny jej eklezjologiczny wymiar. W opracowaniu tym wykazano, iż Sobór wprost nie odniósł się do problemu autonomii porządków prawnych Wspólnot eklezjalnych. W nauce soborowej uznano jednak status tych społeczności. Zmiana pryncypialnego paradygmatu z „Ecclesia Christi est Ecclesia catholica” na „Haec Ecclesia subsitit in Ecclesia catholica" (KK 8, DE 4; DWR 1) stała się przyczyną sprawczą nowego namysłu nad zasadniczym problemem tego studium. Podjęte w okresie posoborowym prace badawcze takich kanonistów, jak J. Prader, czy R. Sobański zaowocowały tym, iż w ówczesnej doktrynie w sposób pośredni z tekstów soborowych zaczęto wywodzić zdatność Wspólnot kościelnych do stanowienia własnego, autonomicznego prawa.

Ewolucyjna zmiana podejścia do interesującej nas kwestii znalazła odzwierciedlenie w pracach kodyfikacyjnych nad pierwszym Kodeksem Katolickich Kościołów Wschodnich. Pod koniec lat 70. ubiegłego wieku konsultorzy postulowali uznanie zdolności do stanowienia prawa Wspólnot kościelnych. Zgłaszane w tym czasie postulaty zostały zwieńczone skodyfikowaniem kan. 780 § 2, n. 1 KKKW w którym w sposób wyraźny zaakceptowano autonomię systemów prawnych wspólnot eklezjalnych. Regulacja o której mowa była zupełnym novum. Podobne rozwiązanie nie występowało w Kodeksie z 1983 r. Stąd też taki stan w legislacji łacińskiej doktryna interpretowała w kategoriach luki prawnej. W związku z tym pojawiły się postulaty w których sugerowano uzupełnienie jej poprzez ustanowienie analogicznego rozwiązania w porządku łacińskim. Nie tylko kanoniści wschodni, ale także kanoniści łacińscy wywodzili zdolność Wspólnot kościelnych z natury społeczności w którą wpisane są elementy eklezjalne. Co więcej, w dniu 27 marca 1998 r. w wyroku Roty Rzymskiej c. Stankiewicz po raz pierwszy uznano tego typu status w odniesieniu do wspólnot protestanckich. Przełomem w długim procesie stało się wprowadzenie art. $2 \S 2$, n. 1 DC posiadającego analogiczną treść jak kan. $780 \S 2$, n. 1 KKKW. Tym samym akceptacja systemów prawnych w porządku łacińskim stała się faktem. 
Tego typu rozwiązanie jest ze wszechmiar słuszne. Wspólnoty kościelne Zachodu bowiem stanowiły i stanowią własne prawo. Pod wpływem uwarunkowań historycznych niejednokrotnie funkcjonujące rozwiązania pozostawały w ścisłym związku z prawem świeckim, bądź też były recypowane z prawa świeckiego. Stąd też w doktrynie pojawiały się poglądy kwestionujące zdatność tych społeczności do stanowienia własnego prawa. W monografii ,Die Ehe von/mit nichtkatholiken vor der Lateinischen Kirche” B. Berkmann określił wyznaczniki świadczące o posiadaniu przez wspólnoty eklezjalne własnego systemu prawnego. W jego opinii, jeżeli wspólnoty reformowane wypracowują własny porządek prawny niezależny od państwa, wówczas należy mówić o ich zdolności do ustanowienia własnego systemu prawnego ${ }^{45}$.

Takie porządki we wspólnotach eklezjalnych istnieją. Świadczą o tym $\mathrm{m}$. in. publikacje na ten temat ${ }^{46}$. W rozważaniach nad tym problemem trzeba jednak być świadomym tego, że w tego typu społecznościach nie istnieje jeden, lecz wiele porządków prawnych ${ }^{47}$. Poszczególne wspólnoty bowiem w stanowieniu prawa posiadają dużą autonomię. Stąd też w literaturze przedmiotu pojawiają się sugestie postulujące stworzenie jednego, wspólnego systemu prawnego ${ }^{48}$. Wydaje się jednak, iż zrealizowanie tych idei jest sprawą dalekiej przyszłości.

${ }^{45}$ B. Berkmann, Die Ehe..., s. 75: ,Wenn die kirchlichen Gemeinschaften auch die Fähigkeit besitzen, sich nach eigenem Recht zu leiten, so ist damit noch nicht die Frage geklärt, in welchen Umfang sie davon tatsächlich Gebrauch machen. Während die reformierte kirchlichen Gemeinschaften ihr Rechtsleben unabhängig vom Staat und oft gegen ihm entwickeln hatten, hielten die evangelischen sich bei der Ausbildung eines Kirchenrechtssystem eher zurück [...]". Szerzej na ten temat zob. A. FERARRI, Il diritto delle Chiese evangeliche, w: Introduzioe al diritto comparato delle religioni, red. S. Ferrari, A. Neri, Lugano 2007, s. 115-134.

${ }^{46}$ Por. D. KonRad, Der Rang und die grundlegende Bedeutung des Kirchenrechts im Verständnis der Evangelischen Kirche, Tübingen 2010; P. LANDAU, Grundlagen und Geschichte des evangelischen Kirchenrecht und des Staatskirchenrechts, Tübingen 2010. Wspólnoty luterańskie w Niemczech w Tybindze wydają od 1951 r. periodyk „Zeitschrift für evangelisches Kirchenrecht”.

${ }^{47}$ Szerzej na ten temat G. LonG, Ordinamenti giuridici delle chiese protestanti, Bologna 2008.

${ }^{48}$ Por. J. Luther, Per un diritto commune delle confessioni protestanti, Daimon 9(2009), s. 215-220. 
Pluralizm porządków prawnych wspólnot eklezjalnych jest faktem. Taki stan stanowi poważny problem w faktycznej recepcji tych rozwiązań w porządku prawnym Kościoła katolickiego. Akceptując dane ustalenie autorytet katolicki musi najpierw dobrze poznać regulacje oraz doktrynę co do danej dyspozycji występującej w danej Wspólnocie eklezjalnej, aby ją zaaplikować w systemie kanonicznym.

\section{The process of acknowledging the autonomy of the laws of Ecclesial Communities in the canonical legal order}

The analysis of the Catholic discipline and doctrine shows that the acceptance of the capability of ecclesial communities to create their own legal systems was a long-term process. The Second Vatican Council and post-council canons were of crucial influence on the present legal order and the solution of the problem.

The author proved that the evolution of the approach of the Church to the question formulated in the title of the article was expressed in the regulations included in can. $780 \S 2$, n. 1 CCCIC and art. $2 \S 2$, n. 1 DC, in which the autonomy of the laws of ecclesial communities was clearly acknowledged.

SŁowA KLUCZowE: prawo własne, Wspólnoty kościelne, system kanoniczny

KeY wORDS: one's own law, ecclesial communities, canonical system 